\title{
Non Performing Assets: A Study on Public Sector Banks in India
}

Prof. Dharmananda M, Assistant Professor, Department of Management Studies, Nitte Meenakshi Institute of Technology, Yelahanka, Bengaluru-64

Dr. Anjali Ganesh, Professor, Department of Business Administration, St. Joseph Engineering College Vamanjoor, Mangalore- 575028

\section{ABSTRACT}

Keywords: Banks, Loan, Recovery, NPA, Economic development, Operational risk
Banks play an important role in the economic development of a country. As Banks are growing, the banking sectors will be exposed to different risks namely credit risk, liquidity risk, interest risk, market risk, operational risk and management risk. The very important risk which the bank faces is recovering the loan. The financial status of the bank will be depending upon the status of the loan recovery and the level of NPA. Reduction in the level of NPA shows that the particular banks have strengthen their processes of credit appraisal system since past few years and increase in Non Performing assets will let down the banks overall profitability. Keeping this view in mind the research tries to explore whether there is any difference in the NPA occurrence between the selected banks from 2014 to 2018 and also the research tries to draw a view on the status of the NPA in selected public sector banks.

\section{INTRODUCTION}

An asset, including a leased asset, becomes nonperforming when it ceases to generate income for the bank and is then termed as Non-Performing Asset (NPA). According to Reserve Bank of India, Non Performing Asset is the interest or instalment has been remained past due for a particular time period which is regulated by Reserve Bank of India. Non Performing Asset becomes very much important in order to analyze the financial performance of a bank and it yield in elevated provisioning desires and accordingly there is a decrease in the margin. It hits liquidity and profitability, in addition to pretension hazard on asset quality and banks survival. It states the banks credit risk. Since last 25 years the concept of NPA has been emerged in the system of our banking sector and passing the unsatisfactory signs on the survival of the pretentious banks. Now a day's public sectors banks have got more affected than private sectors banks in terms of NPA. The higher the level of Non Performing assets at the banking sector can rigorously hit the country's economy in several ways. If the banks are not maintaining their NPA'S properly then there is a cause for financial and economic poverty which helps to create adverse investment due. 
Major causes for increase in Non Performing Assets (NPAs) of Banks

One of the very difficult tasks for the banking sector is to raise the NPAs. The public sector banks will have more problems than private sector banks and foreign banks.

\section{Wilful Defaulters:}

We have seen an increase in mal-administration by the corporate in the country in terms of wilful defaults by showing lack of morale to repay loans. There are borrowers who are competent to pay back loans but are intentionally or unintentionally refrain from repayment. "We do not punish the defaulters and wrong- doers unless he is small and weak. No one wants to go after the rich and wellconnected wrong-doer, which means they get away with even more." -Raghuram Rajan, Former RBI Governor and Indian Economist.

\section{Bad Lending Practices:}

As banks are not following the transparent way of providing loans, the concept of NPAs will arise. The increase in NPAs because of the diversification of business funds, poor system of credit appraisal, no proper credit assessment practices and banks are lending loans to those who are not able to repay the loan.

\section{Over-expectation of economic growth:}

Indian banking sector have been disbursed more credit during the boom period of the business cycle because of over-expectation of economic growth in future. Indian government has implemented the demonetization and GST; the economy couldn't achieve the specified targets.

\section{Natural hazards:}

Every year India is hit by major natural calamities in one or other part of the country. Thus, making the borrowers unable to pay back their loans. Irregularities of rain fall and other event reduces production, the farmers are not able to repay the loans. The bank has to make large amount of provisions in order to pay damages to those loans, hence they end up with a reduced profit.

\section{Severe Competition:}

Severe competition in any particular market segment leads to rise in NPAs. In the anxiety to attain business targets the rules and procedures for prudent banking were conveniently forgotten.

\section{Misgovernance:}

Misgovernance and policy system hampers the timeline and working of the banks. Political interference in the functioning of the public sector banks and providing huge loans to their known has major impact on rising NPAs. Political pressure in selection of Chairman and heads of the banks by the Government is also a cause of concern.

\section{General slowdown of Industrial sector:}

There is a faster growth in NPAs due to slowdown in the Indian economy. The banks that finance those industries ultimately end up with a low recovery of their loans reducing their profit and liquidity.

\section{Ineffective recovery tribunal:}

Although vigilance mechanisms exist, but lack of penalties enforcement means that wrongdoing is 
neglected. The Govt. has set recovery tribunals, which works for recovery of loans and advances, due to their carelessness and ineffectiveness in their work and the perception of wait and watch makes the bank suffers the consequence of nonrecovery, thereby reducing profitability.

\section{Financial Burden:}

The execution of any government's scheme fall over public sector banks. Banks continued to be the primary source of long-term big-ticket investment projects in India, from roads and ports to power and steel. This increases the financial burden on banks. The Infrastructure sector is facing this problem.

\section{Lack of Management information system:}

As banks have a poor Management information system, which leads to poor credit collection and allocation. If there is no proper MIS, banks can't take time to time decisions.

\section{LITERATURE REVIEW}

Dutta. A (2014) conducted a research on NPA Management of Indian Commercial Banks and he examined that there is a growth in the public and private sector banks in India and also he had analysed the study sector wise. He had used secondary data for his research; the sources of secondary data are report on trend and progress of Banking with specific to India, Report on RBI, Reserve Bank of India Economic Survey.

Das, S. (2010) made a research on Management of Non-Performing Assets in Indian Public Sector
Banks with Special Reference to Jharkhand. He examined and tried to find out what were the reasons to have NPAs and study concludes that because of market failure, intractable defaults, poor follow-up and lack of supervision, non support from banks, poor legal framework, poor entrepreneurial skills and diversion of funds.

Ahmad, Z., Jegadeeshwaran, M. (2013) made a research on NPA Management of Nationalised Banks: A Comparative Study. In his research he tried find out the concepts of NPA and the NPA causes. He had used the secondary data for a period of 5 years and he has done the analysis of mean, CAGR, ANOVA and ranking banks. According to the performance in managing the NPA's the banks were ranked. The banks were tested as per the efficiency in managing the NPA by the nationalised banks.

Ranjan, R., Dhal, S.C. (2013) made a research on Non Performing Loans and Terms of Credit of Public Sector Banks in India. In his research he tried to explore non performing loans of Indian commercial banks by using regression. The study revealed that how the non performing loans are influenced by economic and financial factors namely terms of credit, bank size, macroeconomic factors and risk preferences.

Reddy, P.K. (2002): He tried to explore the NPA's in Asian countries about the NPA concept and causes of NPA. Also effort is put to know the effect of the reforms on the NPA level and suggestion for mechanisms to handle the situation by knowing the experiences from different countries. 
Joseph, A. L. (2014): He examined to know the trends in NPA in banking sector and the factors which contributes in raising the NPA in banking sector. And also to give certain suggestions to decrease the NPA burden.

Kamra, S. D. (2013): He conducted a study to analyse the NPA's position in the selected nationalised banks such as SBI, PNB and Central Bank of India. The research also focused to know the policies which implemented by the banks to handle the NPA's and to suggest a suitable strategy for recovery of Patidar, S.,Kataria, A. (2012) studied on "Analysis of Non Performing Assets in priority sector lending: A comparative study between public sector and private sector banks in India" and he examined the analysis of percentage share of NPA 's components of priority sector lending, for SBI and its associates, the comparative study have been conducted to know he significant difference of the non performing assets and also to know the significant impacts of the priority sector lending by using various statistical tools namely regression and analysis of ratios.

\section{Arora, N., Ostwal, N. (2014) studied on}

Unearthing the Epidemic of NPA's: A study conducted of private sectors and public sectors banks. The research analysed and summarised the loans and compared between both public sectors and private sectors banks. The study found that NPA's are the threats for the banking sector as well as for the financial institutions. Comparatively the public sector banks will have the higher NPA's.

\section{OBJECTIVE OF THE STUDY}

-To know the NPA's of all public sector banks.

-To explore is there any variances between public sector banks NPA's

\section{RESEARCH METHODOLOGY}

The study have been conducted for various public sector banks such as Allahabad bank, Andhra bank, BOB, BOI, BOM, Canara bank, Central bank of India, corporation bank, Dena bank, IDBI, Indian Bank, Indian overseas bank, oriental bank of commerce, Punjab and Sind Bank, PNB, SBI, Syndicate bank, UCO bank, UBI, Vijaya Bank.

The study starting from 2014 to 2018, and the Net NPA for last five years have been considered for the study and based on these data analysis have been carried out. The secondary data has been used for the current study and the data was taken from the RBI report and Anova has been used to analyse the data.

\section{RESEARCH HYPOTHESIS:}

H1: There is a significant difference in mean variation between the NPA's of the banks.

Analysis and Interpretation of data

\section{SUMMARY}

\begin{tabular}{|c|c|c|c|c|}
\hline Groups & Count & Sum & Average & Variance \\
\hline 2014 & 21 & 41.96 & 1.998095 & 0.614006 \\
\hline 2015 & 21 & 44.47 & 2.117619 & 0.709149 \\
\hline 2016 & 21 & 46.63 & 2.220476 & 0.935445 \\
\hline 2017 & 21 & 47.64 & 2.268571 & 0.838393 \\
\hline 2018 & 21 & 50.67 & 2.412857 & 0.872091 \\
\hline
\end{tabular}




\section{ANOVA}

\begin{tabular}{|c|c|c|c|c|c|c|}
\hline $\begin{array}{c}\text { Source of } \\
\text { Variation }\end{array}$ & $S S$ & d.f & $M S$ & $F$ & P-value & $F$ crit \\
\hline $\begin{array}{c}\text { Between } \\
\text { Groups }\end{array}$ & 2.0563 & 4 & 0.514078 & 0.647602 & 0.62987 & 2.462615 \\
\hline $\begin{array}{l}\text { Within } \\
\text { Groups }\end{array}$ & 79.382 & 100 & 0.793817 & & & \\
\hline Total & 81.438 & 104 & & & & \\
\hline
\end{tabular}

It is understood that ifF-Value is higher than the PValue, then null hypothesis will be rejected and alternative hypothesis will be accepted and Vice versa (i.e. if F-value is lesser than P Value, then null hypothesis will be accepted and alternative hypothesis will be rejected) .

From the above analysis we can see that $\mathrm{F}=0.647$ $>0.629$, which is significant, now as F-value is higher than $\mathrm{P}$ value, one could conclude that, there is significant mean variation between the NPAs of the Public Sector Banks. Here, null hypothesis is rejected and alternative hypothesis is accepted.

\section{SUGGESTIONS}

- Revised existing credit appraisal and monitoring systems from RBI.

-There must be proper loan recovery methods from each bank.

-All the public sector banks must concentrate on the Credit appraisal and post-loan monitor.

-It is responsibility of the banker to follow-up the customers in each and every steps to make sure that all the loans are recovered.

-After sanctioning the loan by the banker, the banker should visit personally and further close monitoring of the operations of the accounts of borrowed units should be done at regular intervals.

\section{CONCLUSION}

NPA's are subject to major concerns of banking industry as well as other non- banking financial institutions. If the loan amount doesn't meet the actual principal amount, then what ever the interest payment is considered as NPA's. In this research, researcher tried to find out the various types of Non-Performing Assets and causes of NPA and its impact on banking industry as well as to the economy of the country. The secondary data has been used for the study and all the public sector banks have been considered for the study. The data of five years starting from 2014-2018 have taken for the study. The Anova has been used to analyse data. The purpose of the study is to know whether there is a difference in the occurrence between the public sector banks during the study period. The study concludes that there is a significant difference between the means of NPA of public sector banks at $5 \%$ level of significance. The study infers that banks will have a different NPA's respective of their operations in the recent years.

\section{REFERENCES}

-Ahmad, Z. J. (2013). Comparative Study on NPA Management of Nationalised Banks. International Journal of Marketing, Financial Services and Management Research, Vol.2, No.8.

- Das, S. (2010). Management of Non- Performing Assets in Public Sector Banks with Special Reference to Jharkhand.

-Dutta, A. (2014). Empirical Study onNon- Performing Assets Managemnt of Indian Commercial Sector Banks. Vol6 18-22.

- Joseph A.L, P. M. (2014). A study on Analysisng the Trend of NPA level in Private setor Banks and Public sector Banks. Volume 4, Issue 7.

- N, A. N. (2014). Unearthing the Epidemic of NPA's: A study of Public and Private sector Banks. Vol.X.No.1.

-Patidar.S., K. A. (2012). Analysis of NPA in Priority Sector Lending: A Comparative Study between Public Sector Banks and Private Sector Banks of India. Volume 3, No.1. 
-Ranjan, R. D. (2003). Non-Performing Loans and Terms of Credit of Public Sector Banks in India: An Empirical Assessment. Vol.24, No.3.

-Reddy, P. (n.d.). A comparative study of Nonperforming Assets in India in the Global context . 2002.

-Samir, K. D. (2013). A Comparative Analysis of NPAs of selected commercial Banks in India Opinion. International Journal of Managemnt, Vol.3, No.1. 